\title{
Mundos en palabras: learning advanced Spanish through translation
}

\section{Lucía Pintado Gutiérrez}

To cite this article: Lucía Pintado Gutiérrez (2018) Mundos en palabras: learning advanced Spanish through translation, Hispanic Research Journal, 19:3, 323-324, DOI: 10.1080/14682737.2018.1467872

To link to this article: https://doi.org/10.1080/14682737.2018.1467872

\section{Published online: 20 Jun 2018.}

Submit your article to this journal $\square$

\section{山 Article views: 58}

Q View related articles $₫$

View Crossmark data ¿ 
and energy-sector including Vale do Rio Doce and petroleum Petrobrás both enticing skilled foreigners. Its international airports connect it globally and its cosmopolitanism 'reinforces the reach of international megaevents' (242), including, at the time of publication, the forthcoming 2016 summer Olympics and Paralympic games.

By way of conclusion, the review of this excellent and diverse collection and translation into English of 450 years of documents on Rio refers back to its early colonial history. Attention is drawn to the seminal 'On Brazilian Savages' (19-23) by French Protestant seminarian Jean de Léry whose compelling descriptions of the native peoples of Guanabara and their interactions with Europeans 'helped construct in the European mind the image of a "noble savage" taken up by early modern humanists such as Michel de Montaigne' (19).

Else R. P. Vieira

Queen Mary University of London

Q e.vieira@qmul.ac.uk

(C) 2018 Else R. P. Vieira

https://doi.org/10.1080/14682737.2018.1467871

Check for updates

\section{Mundos en palabras: learning advanced Spanish through translation, by}

Ángeles Carreres, María Noriega-Sánchez and Carme Calduch. London, Routledge, 2018. 408 pp. $£ 34.99$ (paperback). $£ 110.00$ (hardback). $£ 34.99$ (eBook).

ISBN 978-1315162379; 9780415695367; 9780415695374

Mundos en palabras is a most welcome publication that proposes an informed use of translation in the foreign language (FL) classroom. This volume is in line with the latest pedagogical trends in language and translation and advocates applying the didactics of professional translation on the assumption that working on this framework (a) will improve the FL learner's language and translating skills and (b) will maximise the pedagogical potential of translation in language teaching and learning. Thus, this book is predicated on a natural and positive exchange between translation studies and language pedagogy within the plurilingual paradigm in language teaching and learning. The handbook reflects the dynamic nature of translation and the sound principles of pedagogical translation - an element that has undergone significant revision in recent decades.

The handbook is an exceptional contribution to the field of language learning - and in particular in Spanish as a FL, as no similar volumes exist. It is of a predominantly practical focus and includes a wide range of translation tasks dealing with salient linguistic and cultural archetypical features for advanced learners of Spanish with English as a source language. It is important to note that this volume is student-centred and that it emphasizes the negotiating principles of the translation process. It ultimately aims to support learners to improve their command of the foreign language and to work on translation as a key skill for any language learner: language learning and translation are complementary and feed into one another. This volume is exciting and unique on the market and a comprehensive guide for any educator who wishes to bring translation to other learning contexts.

The most significant translation theories and concepts relevant to translation practice serve as a basis for students to understand and reflect upon what is entailed by translation. The activities and tasks are based on these considerations, explanations and discussions and give students the opportunity to explore them in depth. In this sense, all chapters integrate theoretical points and discussions within the activities themselves. The first three chapters deal with introductory aspects on translation and identify critical aspects. Chapter 1 looks at translation 
as a communicative process; chapter 2 explores essential elements in translating (translation strategies and techniques; the textual analysis; the translation brief); and chapter 3 examines the resources that a translator works with (sources, dictionaries, glossaries, terminological terms, corpus, etc.). Chapter 4 acts as a natural bridge between chapters 1-3 and 5-12 as it explains the association between textual genres and translation. The content of chapters 5-12 is based on this approach and focuses on textual genre and subgenre(s). Following an explanation of the main features and structures, the authors suggest specific tasks that involve working on key pragmatic, syntactic, morphological, and lexical aspects that are in close relation to the textual type and its attributes concerning translation. Chapters 5 to 10 focus on text types (expository-argumentative, literary, comics and theatre), whilst chapter 11 broadens the spectrum of translation types by timely incorporating audiovisual translation, and finally chapter 12 explores the matter of linguistic variation and translation.

Most chapters include a translation brief as a closing activity, which encompasses the complexities of the elements explored in the chapter and which reflects 'a real-world translation commission'. The book structure is clear and the sequence between the chapters, the explanations and tasks is well-defined, coherent, and cohesive, which makes it easy to follow for all potential readers whether teachers, learners or independent users. Tasks generally involve translation into the L2, but also into the L1 (there are intralingual activities as well), and (most) tasks included in this volume do not have a correct/incorrect answer but, in the spirit of being helpful for independent learners, the volume offers an 'answer key' which can be found on the digital platform that complements the handbook and which includes further activities and useful resources. There is also a guide for teachers should they need suggestions on how to use the material. Teachers may adapt the book to the needs of the students or to different teaching contexts. Thus, this contribution is a versatile tool which promotes independent learning but also collaborative learning though discussions in pairs or groups.

Materials include the introduction and the discussion of some of the main theories and approaches to translation studies, excerpts from various types of texts (literary texts, songs, poems, audio-visual extracts). The main content is presented in Spanish, although some of the material and quotes are in English. The writing style and the transition between tasks makes this a comprehensible, consistent, and very enjoyable handbook.

Mundos en palabras takes on the translation turn in FL pedagogy and provides a rationale to include translation as a significant element; it is an innovative contribution that brings together the quintessential theoretical aspects and substantial practice. This handbook is a challenging and multifaceted volume and without a doubt educators, learners, and practitioners will embrace it as an essential tool in the classroom. It shows a firm commitment to bring to the curriculum and the FL classroom the most informed pedagogical practices. The engaging and comprehensive nature of the tasks developed allows the reader to explore a wide range of aspects while catering for a wide profile of learners. The handbook is highly recommended: it is time for educators to explore the potential of translation in the language classroom consistently and this book provides the necessary support. Due to the variety of the material and the typology of the activities this handbook may be used in the language classroom but also by students training to become translators.

Lucía Pintado Gutiérrez

Dublin City University

Q lucia.pintado@dcu.ie

(C) 2018 Lucía Pintado Gutiérrez https://doi.org/10.1080/14682737.2018.1467872 